Zagłada Żydów. Studia i Materiały, R. 2020, nr 16

ISSN (print): 1895-247X; eISSN: 2657-3571

DOI: https://doi.org/10.32927/ZZSiM.642

\title{
Przemysław Nowicki
}

Włocławskie Towarzystwo Naukowe, Polskie Towarzystwo Historyczne o/Włocławek https://orcid.org/0000-0002-2026-5642

p.novitzky@wp.pl

\section{Łucja Pawlicka-Nowak (1938-2020) badaczka Zagłady, prekursorka archeologii miejsc pamięci}

Zmarła 27 lutego 2020 r. w Koninie Łucja Pawlicka-Nowak, archeolożka i historyczka Zagłady w Kraju Warty, była prekursorką badań archeologicznych na terenach po byłym niemieckim obozie zagłady Kulmhof w Chełmnie nad Nerem, pierwszym zorganizowanym miejscu uśmiercenia Żydów na polskich ziemiach wcielonych do Trzeciej Rzeszy. Wyznaczała trendy w nowej dziedzinie archeologii historycznej - archeologii totalitaryzmu - na długo przed pracami badawczymi archeologów, historyków drugiej wojny światowej i prokuratorów w podobnych miejscach pamięci - na terenach poobozowych w Bełżcu i Sobiborze.

Urodziła się 21 stycznia 1938 r. w Poznaniu. Jej rodzicami byli Jan i Matylda Pawliccy. W 1962 r. ukończyła archeologię na Uniwersytecie im. Adama Mickiewicza w Poznaniu, a następnie uzyskała na tej uczelni stopień doktora. W $1963 \mathrm{r}$. wyszła za mąż za kolegę ze studiów, Andrzeja Nowaka. Rok później urodziło się im jedyne dziecko - córka Natalia. W połowie 1967 r. przybyła do Konina, aby rozpocząć pracę w Muzeum Zagłębia Konińskiego, którego jej mąż był kierownikiem. W 1974 r. została powołana na stanowisko dyrektora muzeum, które od 1975 r. przekształcono w Muzeum Okręgowe.

Pawlicka-Nowak zapisała się na kartach historii jako organizatorka utworzonego w 1987 r. Muzeum byłego niemieckiego Obozu Zagłady Kulmhof w Chełmnie nad Nerem, oddziału konińskiej placówki, które z początku obejmowało swym zasięgiem Las Rzuchowski - miejsce pomordowania i zagrzebania ofiar Kulmhof (w 1990 r. oddano tam niewielki pawilon muzealny oraz pobudowano ścianę pamięci-lapidarium). W $1990 \mathrm{r}$. badaczka przyczyniła się do zabezpieczenia macew ze zniszczonego cmentarza żydowskiego w Turku, a następnie do upamiętnienia około dwudziestu cmentarzy znajdujących się w granicach ówczesnego województwa konińskiego, w tym ocalenia ponad sześciuset macew odnalezionych poza cmentarzami. To dzięki zaangażowaniu Pawlickiej-Nowak tereny poobozowe Kulmhof zostały w 1994 r. wpisane do rejestru zabytków. Pod koniec 1997 r. rozpoczęła współpracę z Radą Ochrony Pamięci Walk i Męczeń- 
stwa i jej sekretarzem generalnym Andrzejem Przewoźnikiem (1963-2010). Współpraca w 1998 r. zaowocowała wykupieniem od syndyka masy upadłościowej oraz od osoby prywatnej terenu po byłym założeniu dworskim w Chełmnie, gdzie od grudnia $1941 \mathrm{r}$. Niemcy dokonywali zagłady w samochodach-ruchomych komorach i gdzie do drugiej połowy lat dziewięćdziesiątych XX w. handlowano nawozami, materiałami budowlanymi, węglem, trzodą chlewną i bydłem. W późniejszych latach zaangażowana była przy upamiętnieniach zgładzonych gmin żydowskich (np. z Bełchatowa, Brzezin, Gąbina i Łodzi), zorganizowanych m.in. przez ziomkostwa oraz rodziny i osoby prywatne, w tym córkę ocalałego z Kulmhof Abrama Roja - pierwszego uciekiniera. W 2004 r. wspólnie z Radą Ochrony Pamięci Walk i Męczeństwa i Instytutem Jad Waszem w Jerozolimie zorganizowała międzynarodową sesję naukową, poświęconą najnowszym badaniom nad Kulmhof. W październiku 2006 r. badaczka przeszła na dyrektorską emeryturę i pozostając jeszcze do 2012 r. pracownikiem muzeum, skoncentrowała się wyłącznie nad badaniami związanymi z historią Kulmhof i Zagładą w miejscowościach położonych w Kraju Warty (m.in. w Koninie, Kole i Sompolnie). Do 1998 r. wchodziła w skład Wojewódzkiego Komitetu Ochrony Pamięci Walk i Męczeństwa w Koninie. W latach 2008-2012 i 2012-2016 oraz od 2017 r. do śmierci, była członkinią Komitetu Rady Ochrony Pamięci Walk i Męczeństwa przy oddziale Instytutu Pamięci Narodowej w Poznaniu.

Łucja Pawlicka-Nowak była autorką i redaktorką wielu publikacji naukowych dotyczących dziejów obozu zagłady Kulmhof, powstałych na podstawie badań archeologicznych, które zostały przeprowadzone w Chełmnie pod jej nadzorem w latach 1986-1987 (teren Lasu Rzuchowskiego) oraz 1997-2006 (tereny: przykościelny i przypałacowy). Część z nich publikowała na łamach biuletynu „Przeszłość i Pamięć”, organu Rady Ochrony Pamięci Walk i Męczeństwa w Warszawie ${ }^{1}$. W 1995 r. ukazał się zbiór studiów z pierwszej w Polsce sesji naukowej poświęconej historii Kulmhof, którego współwydawcą było zarządzane przez nią Muzeum Okręgowe w Koninie ${ }^{2}$. W 1996 i, po uzupełnieniach, w 2004 r. ukazały się zbiory artykułów i materiałów źródłowych pt. Mówiq świadkowie Chełmna, które zredagowała sama i wespół ze Shmuelem Krakowskim (w uzupełnionym zbiorze, poza przedmową, znalazły się jej trzy artykuły poświęcone dziejom

${ }^{1}$ Tytuły tych artykułów zob. Łucja Pawlicka-Nowak, Badania archeologiczne na terenie byłego niemieckiego ośrodka zagłady w Chełmnie nad Nerem [w:] Archeologia totalitaryzmu. Ślady represji 1939-1945, red. Olgierd Ławrynowicz, Joanna Żelazko, Łódź: IPN, 2015, s. 141, przypis 19.

${ }^{2}$ Ośrodek zagłady $w$ Chełmnie nad Nerem i jego rola $w$ hitlerowskiej polityce eksterminacyjnej. Materiały z sesji naukowej - Muzeum Okręgowe Konin 24 kwietnia 1995 r., red. Józef Kapustka, Maciej Laba, Zdzisław Lorek, Konin: Główna Komisja Badania Zbrodni Przeciwko Narodowi Polskiemu Instytut Pamięci Narodowej, Rada Ochrony Pamięci Walk i Męczeństwa, Zespół Naukowo-Badawczy ds. Eksterminacji Żydów na Ziemiach Polskich Włączonych do III Rzeszy przy Okręgowej Komisji BZpNP w Łodzi, Wojewoda Koniński, Muzeum Okręgowe w Koninie, 1995. 
upamiętnienia Kulmhof oraz najnowszym badaniom archeologicznym; autorka edytowała też w nim źródła) ${ }^{3}$. W 2004 r. ujrzał światło dzienne tom poświęcony badaniom archeologicznym w Chełmnie, pokłosie wspomnianej już sesji międzynarodowej, którego Pawlicka-Nowak była redaktorką i autorką jednego z artykułów ${ }^{4}$. Była też współautorką albumu Niemieckie obozy zagłady $w$ Polsce, który ukazał się w 2005 r. w języku polskim, a następnie w dziewięciu wersjach obcojęzycznych. Wydany w Gdańsku i liczący ponad 650 stron zbiór Świadectwa Zagłady ${ }^{5}$, niespotykany dotąd w nauce szeroki wybór źródeł do dziejów obozu zagłady Kulmhof i getta wiejskiego w Czachulcu z wprowadzeniem i wstępem historycznym, pozostaje opus vitae tej konińskiej badaczki ${ }^{6}$. Dwa lata później wyszedł w Koninie polskojęzyczny przekład opracowanego przez nią dziennika rabina Aaronsona z Sannik ${ }^{7}$, niezwykle cenne źródło do dziejów obozu pracy przymusowej dla Żydów w Koninie-Czarkowie oraz Kulmhof - książka, która przeszła niemalże bez echa, a zaistniała w mediach ze względu na skandaliczny, ksenofobiczny do niej wstęp, napisany przez dyrektora Muzeum Okręgowego w Koninie, następcę Pawlickiej-Nowak ${ }^{8}$. Autorka była też redaktorem dwóch pierwszych numerów „Konińskich Zeszytów Muzealnych”, a następnie - po wznowieniu tego muzealnego czasopisma - publikowała na ich łamach teksty dotyczące m.in. osób związanych z historią pierwszego masowego miejsca eksterminacji Żydów.

${ }^{3}$ Mówiq świadkowie Chełmna, red. Shmuel (Stefan) Krakowski, Łucja Pawlicka-Nowak, Konin-Łódź: Oficyna Bibliofilów, 1996; Mówia świadkowie Chełmna, red. Łucja Pawlicka-Nowak, wyd. 2, Konin-Łódź: Oficyna Bibliofilów, 2004. Wyd. ang.: Chełmno Witnesses Speak, red. Łucja Pawlicka-Nowak, Konin-Łódź: The Council for the Protection of Memory of Combat and Martyrdom, 2004.

${ }^{4}$ Ośrodek zagłady $w$ Chełmnie nad Nerem $w$ świetle najnowszych badań. Materiały z sesji naukowej: Muzeum Okręgowe w Koninie 6-7 września 2004, red. Łucja Pawlicka-Nowak, Łódź: Oficyna Bibliofilów, 2004. Wyd. ang.: The Extermination Center for Jews in Chetmno-on-Ner in the Light of the Latest Research. Symposium Proceedings: September 6-7, 2004, red. Łucja Pawlicka-Nowak, Łódź: Oficyna Bibliofilów, 2004.

${ }^{5}$ Świadectwa Zagłady. Obóz w Chełmnie nad Nerem. Getto wiejskie Czachulec, wybór dokumentów, wstęp, oprac. Łucja Pawlicka-Nowak przy współudziale Jolanty Adamskiej, Gdańsk: Muzeum II Wojny Światowej, 2014.

${ }^{6}$ Zob. rec. książki: Przemysław Nowicki, Świadectwa Zagłady. Obóz w Chełmnie nad Nerem. Getto wiejskie Czachulec, wybór dokumentów, wstęp, oprac. Łucja Pawlicka-Nowak przy współudziale Jolanty Adamskiej, Gdańsk: Muzeum II Wojny Światowej w Gdańsku, 2014, 654 s. (il. 8) + nlb (plany 3, il. 80), „Zagłada Żydów. Studia i Materiały” 2016, nr 12, s. 561-568.

${ }^{7}$ Jehoszua Mosze Aaronson, Zwój domu niewoli. Dziennik rabina Aaronsona, więźnia niemieckiego obozu dla Żydów w Koninie-Czarkowie 1942-1943, oprac. i przyp. Łucja Pawlicka-Nowak, tłum. z jęz. hebr.: Małgorzata Lipska, wstęp: Lech Stefaniak, Konin: Muzeum Okręgowe, 2016.

${ }^{8}$ Zob. szerzej: Natalia Mazur, Ciekawa książka, fatalny wstęp, „Gazeta Wyborcza” (Poznań), 22 VIII 2018 r. Zob. również: https://poznan.wyborcza.pl/poznan/7,36001,23806309,porownal-obozowe-wspomnienia-zyda-do-lewackich-banialuk-drenujacych.html (dostęp $18 \mathrm{~V}$ 2020 r.). 
Jej wielkim i niezrealizowanym marzeniem było utworzenie w Chełmnie małego ośrodka badań nad Zagładą w Kraju Warty. Pracowała nad zagładowymi źródłami niemal do samego końca. Badała w archiwach przebieg procesów nazistowskich zbrodniarzy, czytała zeznania ocalałych z Zagłady, kolekcjonowała relacje i zdjęcia, przeglądała listy transportowe $\mathrm{z}$ łódzkiego getta do Kulmhof. Z jidyszystką i studentami Instytutu Historii Uniwersytetu Warszawskiego przygotowała do wydania w języku polskim nieznaną dotąd badaczom relację Mordechaja Żurawskiego - jednego z uciekinierów z drugiego etapu funkcjonowania Kulmhof - która ukazuje się w tym numerze pisma. W ostatnim okresie życia pracowała też nad historią getta żychlińskiego.

Dla historyków oraz muzealników pozostanie na zawsze w pamięci osobą skromną i nieszukającą rozgłosu. Podczas rozmowy cechował ją „spokojny i rytmiczny ton wypowiadanych słów". W muzeum otaczała opieką bezdomne koty, które w jej służbowym gabinecie przechadzały się wśród książek, kartek papieru kserograficznego i fiszek. W niewielkim konińskim mieszkaniu hodowała krótkowłose persy, które prezentowała na wystawach krajowych i zagranicznych. Ceniła dzieła dawnych mistrzów europejskiego malarstwa. Muzycznie fascynował ją Karol Szymanowski, a przy utworach Jana Sebastiana Bacha „zamieniała się w słup soli". Regularnie oddawała się lekturze ulubionych autorów książek - Williama Szekspira, Michaiła Bułhakowa i Szaloma Asza.

Pogrzeb Łucji Pawlickiej-Nowak odbył się 5 marca 2020 r. na cmentarzu w Koninie-Gosławicach, położonym w sąsiedztwie Muzeum Okręgowego - zgodnie z jej ostatnim życzeniem. Podczas ceremonii pogrzebowej w kaplicy cmentarnej przemawiał m.in. ks. Wojciech Lemański, odczytano również pożegnalny list z Gminy Wyznaniowej Żydowskiej w Poznaniu. 